\title{
Original article (full paper) \\ Soccer and homosexuality: The conflicts that lie within the affective game of the coach-adolescent athlete relationship
}

\author{
Altair Moioli \\ Afonso Antônio Machado \\ Marcelo Callegari Zanetti \\ Debra Frances Campbell \\ São Paulo State University, Rio Claro, Brazil \\ António Rui Gomes \\ University of Minho, Braga, Portugal
}

\begin{abstract}
Discussions regarding homosexuality within a sports context are mediated by emotional nuances, especially in the world of soccer, where practitioners are required to have attributes such as strength, masculinity and aggressiveness. As a consequence, this work aimed to analyze the symbolic representation of homosexual relationships between adolescent soccer players and their coaches; and, furthermore, to understand the intention behind homoerotic relationships that are established between members of the management team and its players. In this study, researchers used the life history methodology, with participation from three adolescent athletes, ages 14, 15 and 16, and three former athletes, ages 26, 28 and 45, who we called speakers. Based on the collection and analysis of research participants' testimonies, homosexual relations were found to have occurred between athletes and coaches, or between athletes and other members of the management team, as a part of a "social contract" that is exclusively linked to their professional objectives. These relationships appear to be purely objective; authentic affective links are absent, due apparently to the transient nature of the athletes in these groups. Too, this context is usually marked by the athlete's physical and emotional vulnerability, and the agreements he makes within this context are accompanied with moral dilemmas, because such adolescents idealize the coach as a paternal archetype.
\end{abstract}

Keywords: soccer, adolescent, homosexuality, homoerotic, human development and technologies

Resumo - "Futebol e homossexualidade: Os conflitos que se encontram dentro do jogo afetivo da relação treinador-atleta adolescente." As discussões a respeito da homossexualidade no contexto esportivo são mediadas por nuanças emocionais, especialmente no mundo do futebol que exige de seus praticantes atributos de força, virilidade e agressividade. Por este motivo este trabalho teve como objetivos diagnosticar existência de relações homossexuais entre atletas adolescentes da modalidade de futebol e seus técnicos e sua representação simbólica e ainda, compreender a intencionalidade das relações homoafetivas que se estabelecem entre componentes da equipe diretiva e os jogadores. Esta pesquisa é de natureza qualitativa e a técnica adotada foi a "história de vida" e a participação de três atletas adolescentes em atividade, com idade de 14,15 e 16 anos e três ex-atletas profissionais, com idades 26,28 e 45 anos serviram de base metodológica. A partir da análise e tratamento dos depoimentos verificou-se que ocorreram relações homossexuais nas categorias de base envolvendo técnico e atleta, ou com outros membros da equipe diretiva, como parte dos contratos sociais, ligados exclusivamente a objetivos profissionais. Estas relações parecem ser puramente objetais, não parecendo existir vínculos afetivos duradouros, aparentemente, devido à natureza transitória de atletas nesses grupos. Também, nesses ambientes, muitas vezes marcados pela vulnerabilidade física e emocional dos atletas, os acertos para as relações homossexuais são permeadas por dilemas morais, tendo em vista que os atletas adolescentes idealizam o treinador como o arquétipo paterno ideal.

Palavras-chave: futebol, adolescente, homossexualidade, homoerotismo, desenvolvimento humano e tecnologias

Resumen - "El fútbol y la homosexualidad: Los conflictos que se encuentran dentro del juego afectivo de la relación atleta-entrenador de los adolescentes." Las discusiones sobre la homosexualidad en contexto deportivo están mediadas por matices emocionales, sobre todo en el mundo del fútbol que exige a sus jugadores atributos como la fuerza, la virilidad y la agresividad. Por lo tanto, este estudio tuvo como objetivo diagnosticar la existencia de relaciones homosexuales entre adolescentes atletas de fútbol y sus entrenadores y la representación simbólica de estas relaciones. También comprender la intencionalidad de las relaciones homoafetivas que se intercambian entre algunos componentes del equipo directivo y 


\begin{abstract}
los jugadores. En este estudio, los investigadores utilizaron la metodología de la historia de vida, con la participación de tres atletas adolescentes, con 14, 15 y 16 años, y tres ex atletas con 26, 28 y 45 años, que llamamos 'oradores'. Basado en la recogida y análisis de testimonios de participantes en la investigación, se encontró que las relaciones homosexuales que se han producido entre los atletas y entrenadores, o entre atletas y otros miembros del equipo de gestión, son como parte de un "contrato social" que está vinculado exclusivamente a sus objetivos profesionales. Estas relaciones parecen ser solamente como un objeto; porque a veces no hay vínculos afectivos auténticos, debido aparentemente a la naturaleza transitoria de los atletas en estos grupos. Demasiado, este contexto es generalmente marcado por la vulnerabilidad física y emocional del deportista, y los acuerdos que hace dentro de este contexto se acompañan con dilemas morales, debido a que tales adolescentes idealizan el entrenador como un arquetipo paterno.
\end{abstract}

Palabras clave: fútbol, adolescente, homosexualidad, homoerotismo, tecnologías y desarrollo humano

\section{Introduction}

Ancient philosophers, including Plato, noted that issues related to sexuality are phenomena that are linked to the socio-psychological aspects of being human (Badinter, 1993). Discussions and studies about sexual identity have occurred throughout history, and, yet today, they still cause discomfort because, often, they are associated with certain taboos. Additionally, they generate ideological conflicts and are frequently marked by divergent opinions and social and moral dilemmas (Fávero, 2010).

Desires and sensations stimulate such human relationships, and target aesthetic vanity, the veneration of beauty, the eroticization of the body, and feed Western culture's constant search for the perfect body (Canevacci, 2008). Both body narcissism and fetishes are behaviors that people develop in order to guarantee their space in their social group (Canevacci, 2008).

Kehl (2003) supports the idea of an object body, which, he claims, belongs to the individual less than he or she imagines. Its function is to serve certain collective demands and to symbolically express the characteristics of the individual's social setting. For example, concerning the practice of soccer, the individual carries in his body the myth of hero through social representations of strength, bravery, and virility.

Sports, especially team sports such as men's soccer, constitute an environment in which the body can be considered as one of the most active elements in the regulation of personal, professional, emotional, and sentimental relationships amongst team members. Therefore, these athletes are not immune to the emotional states that result from the high level of exposition of their bodies (Del Percio, 2012; Machado, 2006).

The game of professional soccer is constituted by what appears to be an exclusively heterosexual culture. That is, in order to participate in the world of soccer, players must adapt themselves in accordance with pre-established heterosexual rules and norms (Machado, 2006). Fávero (2010) observes that a masculine ideology, based in the valuation of aggressiveness and violence, helps to define the social roles of men and women.

Some homosexual players only feel free to make themselves visible after their careers have ended, because to do so earlier would likely result in not having their contracts renewed or in a loss of respect by their teammates (Lahn, 2010; Townsend, 2013). Examples of such players are Thomas Hitzlsperger, former soccer player for the German national team (Christenson, 2014) and Robbie Rogers, an American, and former soccer player for the English Leeds United team (McRae, 2013).
In this context, the act of revealing homosexual relationships that occur within and throughout the game of soccer could undermine the culturally established archetype that traditionally has been idealized by the participants of this social group. Therefore, secrecy about such relationships is highly mandated for all parties involved in the sport (Franco Junior, 2007).

Social and cultural representations of soccer continue to reflect this mandate, even in a postmodern society that is experiencing changes relative to tolerance toward homosexual relationships. Despite this, society still expects "traditional" behavior in soccer players, characterized by virility, strength, and power (Badinter, 1993; Fávero, 2010).

Therefore, to investigate a subject with such extreme partisanship and popularity as soccer is to set in motion a complex game of metaphors, symbolic appropriations, and social representations (Moscovici, 2001). This game, in which social practices are consolidated and conventional masculine attributes are reinforced, as was earlier noted does not make explicit the existence of homosexual relationships.

Thus, soccer culture creates only a very specific model of man who is eligible to belong to the sporting world. Children are born and grow up steeped in activities that typify the sport, and, as future athletes, they envision the possibility of economic and social mobility and recognition only by becoming this type of man.

\section{Background of the problem}

The day-to-day sports environment in which soccer is played is filled with sensations and emotions for all participants-whether they are athletes, coaches, officials, media representatives, or fans - that make them co-dependent on the professional and personal actions of others (Franco, 2007; Rodrigues Filho, 2003). These actions foster a network of common interests marked by interpersonal relationships, and by emotional and sexual consequences. As a result, soccer has become an important area of research in the fields of physiology, philosophy, sociology, and psychology (Giulianotti, 2002; Helal, Lovisolo, \& Soares, 2011; Machado, 2011; Rohden, Azevedo, \& Azanbuja, 2012; Simon, 2006).

This work has resulted in a body of research based on the social representation of soccer and its subjectivities, which are intrinsic to this environment. These subjectivities are important psychological elements in the integral formation of young athletes (Moscovici, 2001). Thus, it is possible to explore 
complex issues that escape the foci of traditional studies that are related only to physiological and technical aspects of the sport. The topic of homosexuality in soccer, therefore, has not been widely researched, it seems, because it is a phenomenon that lies outside of what is thought to be typical behavior for an athlete (Anderson, 2005).

The soccer environment encompasses attributes and attitudes of strict virility - affective and sexual behaviors that are popularly associated with heterosexuality. As such, they are intensively monitored and evaluated by associated members of the group: team mates, fans, friends, and family (Anderson, 2013; Hargreaves \& Anderson, 2014). This vigilance is facilitated through an athlete's persistent media exhibition, which reflects the requisite alpha male image (Anderson, 2005).

A challenge inherent in this study was the difficulty in documenting behaviors that are considered taboo in order to determine the motives behind the relationships between athletes and members of the team's executive committees - especially coaches, and to determine why and when these sexual relations occur. Too, special consideration was required due to the age of the younger participants. We protected all participants by assuring that their identities were carefully guarded.

\section{Literature review}

The literature review concentrated on phenomena that contribute to, and interfere with, adolescent development, especially as they relate to the social and cultural characteristics of sport. The review focused especially on the dynamics of gender, and the relationship between different contexts such as sports and social settings. As noted by Anderson and Hargreaves (2014), this relationship contributes to the formation of human sexuality, and often is regulated by ideologies, labor relations, and relations of power. This makes gender segregation - the formation of identities and their affective relationships - more evident.

\section{Soccer and the social construction of masculinity}

Competition is about winning and losing. Winning is traditionally linked to the conquest of hegemonic power, and as one of the major instruments of social assessment, it provides fame and power to the winner (Machado, Presoto, \& Gouveia, 2006).

As suggested by Betti (1991), we can make an analogy between sports competition and the varied social struggles. These struggles typically involve a search for social and economic mobility, or political, cultural and ideological freedom. Sport, as a means of competition, is related to these aspects.

Throughout history, sport has been a strong influence on behavior, due to its references to masculinity, strength, aggression, and force, and because of its perceived ability to transform boys into men (Anderson, 2013; Hargreaves \& Anderson, 2014; Whitson, 1990). The need to maintain the ideal of masculinity, thus, involves man in a never-ending struggle to live according to his assigned social rules. Present-day masculinity is measured by success, financial independence, professional aggressiveness, social position, and the amount of power achieved; that is, "super macho" defines the ideal role (Badinter, 1993, 1998; Hanna, 1999; Machado, 2002; Meroni, 2011). Therefore, social and cultural conventions require boys to be a "man"-rude, crude, virile, and vigorous as a symbol of masculinity, while girls are required to be feminine, sweet, sensitive, gentle, and loving (Fávero, 2010). Badinter (1993) claimed that, in the absence of strong and close ties and a personal identification with the father, the boy will choose famous men as role models. He observed that they will develop moral values and attributes of the "macho man," based on the accepted ideal of masculinity.

These observations correspond with the social representation of soccer. In Brazil, the sport is characterized as an essentially masculine practice (Franco, 2007; Rodrigues, 2003), and the identity formation of its participants colors the relationships and personal contacts that are maintained within this environment (Bock, Furtado, \& Teixeira, 2002). Young athletes must negotiate this environment in extreme periods of social vulnerability caused by loneliness, difficulties in adapting to a new world, unfamiliar living situations, new peer groups, and obligations that arise from this new life phase (Machado, 2006). For example, when adolescents leave their homes to try out for sports teams, they must exchange the security that family represents for an unknown world of sport, an act that requires them to mature suddenly and quickly (Machado, 2002).

Badinter (1993) claimed that the act of constantly trying to achieve ever-increasing, unachievable goals keeps these individuals in an active state of conflict. That is, the search for an idealized behavior that represents the masculine ideal is, for men, a constant and arduous struggle. He described this struggle thusly:

Being a man means not being feminine, not being homosexual, not being docile, dependent or submissive, not being effeminate in appearance or physical gestures, not having sex or intimate relations with other men, not being impotent with women [.. .] (Badinter, 1993, p.117).

In other words, this individual is similar to the archetype of man who is idealized in the world of soccer, an ideal that is thought to guarantee success in a fiercely competitive and segregationist environment.

Biased and discriminatory conduct such as homophobia can be understood as a characteristic of a heterosexual society, an essential component for the maintenance of the hegemonic "male" condition. Homophobia often inhibits the possibility of friendship or affection developing between two men, because they are afraid of being mistaken as gay and having their masculinity challenged (Rodrigues, 2010; Rosa, 2008).

Because heterosexuality is the more socially-accepted form of sexual orientation, it therefore consolidates the hegemony of a culture geared toward creating and maintaining the stereotypical "man." This encourages the existence and valorization of a phallocentric culture in which "[...] it is, therefore through sex and sexual activity that man best becomes aware of his identity and masculinity" (Badinter, 1993, p.141).

In this context, the soccer player can be considered a reference for models that embody all "masculine" attributes, and 
the sport itself the ideal place to search for these qualities and satisfy the seemingly endless struggle to attain masculinity-associated power and virility (Machado, 2002; Machado, Gouvea, Bartholomeu, \& Moioli, 2008).

\section{Adolescent sexual identity and sports}

Some authors (among them: Aberastury \& Knobel, 1986; Atkinson, Atkinson, Smith, Bem, \& Hoeksema, 2002; Bandura, 1977) suggest that an individual's ability to reproduce certain attitudes, to imitate behaviors, and even to reframe emotional and psychological aspects of real or symbolic models, shape his or her identity construction. These components may represent an individual's assimilation of the cultural values and attitudes that allow him or her to coexist in society and pay allegiance to the group to which he or she belongs. Thus, affective relationships - as determinants in moral value formation and identity development, the social phenomenon of soccer, and the emotional connections that arise as a result this environment, as described above, indeed can all play a role in the athlete's identity construction, as Bredemeier and Shields (1998) suggested.

To this end, Gianmi (1998) reviewed theories of social representation to foster debate about sexuality. In his essay, the author argued for the relevance of culture in discourse on the subject, pointing out social changes, historical periods, and ideology as markers in such debates. Therefore, accordingly, the notion of social representation, within the context of the development of sexuality, is related to dimensions that are individual or collective, public or private, social or psychological, and, notably, occur between object and subject.

Sexuality has always been intrinsically linked to human relationships, and to their values, rules, customs, and moral principles, depending on the lived historical context (Silva, 2000). The discussion of sexuality, beginning with the libertarian conception of sexuality in ancient civilizations (Saraiva, 2011), passing through the epic of "sinful" behaviors in the Middle Ages (Foucault, 1987, 1988; Rios, Parker, \& Terto Junior, 2010), and reaching what is popularly considered social emancipation in postmodern society (Heilborn \& Cabral, 2013), still generates discomfort and causes social, emotional, and religious conflicts (Badinter, 1993; Hanna, 1999; Sedgwick, 2007).

Psychoanalytic theory attempts to make sense of these conflicts. It claims that human behavior is influenced by unconscious and conscious desires that begin at birth and develop throughout the individual's lifetime. This theory suggests that it is up to the unconscious to process phenomena of resistance and repression, and to mediate innate and instinctual impulses and real desires (Perelberg, 2007, 2013). The impulsive actions' balance helps us to internalize the norms, values, and models that establish dualities such as right and wrong, good and bad, and other moral dichotomies (Bronfenbrenner, 2011; Kohlberg, 1992; La Taile, 2010; Rappaport, 2007).

Different theories of human development point to a variety of factors that contribute to the definition of sexuality. Using solely biological characteristics, humans differ only in the fact that they are male or female. However, social reinforcement, mechanisms of identification, time spent in school and in peer group formation and existence, and the overall community in which the individual is brought up, all provide fundamental experiences for gender identity formation (Atkinson et al., 2002; Bandura, 1977; Bock et al., 2002; Bronfenbrenner, 2011; Cerqueira, 2011). However, recent studies suggest that gender should be thought of as a continuum, not restricted to either male or female (Swain, 2009).

The adoption of traditionally masculine or feminine roles stems from powerful cultural components, or stimuli, that reinforce the behavioral patterns of each gender (Bozon, 2004; Heilborn, 2006; Heilborn, Duarte, Peixoto, \& Lins de Barros, 2004). These components reinforce cultural models to the extent that the child imitates the conduct of the adult, and consequently receives positive reinforcement for each action associated with the "proper" gender. This reinforcement may be in the form of praise or criticism, depending on whether or not the conduct was appropriate. These actions are representative of social learning theory (Bandura, 1977).

The world of sports adopts these cultural and social components and is, therefore, an optimal space in which to reinforce male and female archetypes. In this network, men are introduced to the vigorous and exclusively "masculine" activities, while women's sports, traditionally, represent activities with less risk and more limited physical contact.

Soccer is largely a product of the media; it is a spectacle (Franco, 2007). As such, vanity plays a large part in reinforcing the identity of teenagers who take part in competitive team sports. This vanity creates a particular style, one that is not only related to aesthetic issues, but, also, and more significantly, to strengthening soccer's image within society. We see an example of this particular style in soccer player Neymar's Mohawk haircut, when he played with the Brazilian soccer club (i.e., Santos Futebol Clube).

We can view such phenomena as evidence that sexual desires and relationships occur under a strong cultural influence, one that is created by a society that prohibits certain behaviors, and which defines behavioral norms and rules of conduct. In this sense, society creates taboos that may interfere with the sexual behavior of adolescents.

Atkinson et al. (2002) concluded that "[...] an individual's sexual orientation is the degree to which he feels sexual attraction to persons of the same and/or opposite sex" (p. 397). Therefore, the identification of sexual preference could be illustrated by a straight line: at one end are exclusively straight (heterosexual) behaviors, and, at the other, exclusively homosexual behaviors. However, other behaviors are scattered between these two extremes and may approach and identify more with one side of the scale than with the other (Cerqueria, 2011; Fávero, 2010; Meroni, 2011). We see, therefore, that the model put forth by soccer media and consumed by the masses doesn't leave space for relationships that are not "heterosexual."

On the playing field, soccer players demonstrate heterosexual preference by kissing their wedding ring after a goal, putting the soccer ball under their shirt to represent their wives' pregnancies, being photographed alongside actresses and models, displaying typically masculine commodities such as luxury cars, 
fancy jewelry, or tattoos, and, most recently, creating personal pages on social networking websites that broadcast the achievements of the man/athlete.

Conversely, soccer players need to hide homosexual preferences, a necessity generated by a fear of losing their hard-won mythical and heroic status - and contracts, and symbolized by masculinity, virility, and heterosexuality. In his recent autobiography, German soccer player Phillip Lahn (Lahn, 2010) argued that gay players should not reveal their sexual preference because to demonstrate homosexual preference is to risk being excluded from the sport. This decision, he said, does not "play by the rules" of a high-performance sport (Mandard, 2003).

The physical, occupational, social, and psychological aspects of young players' developmental phases, as they relate to sexuality, often occur via experiments and discoveries in moments of vulnerability. Yet, within the context of soccer, discussions about the topic of homosexuality typically do not evolve beyond the subject of pornography or erotic banter, and often allow young players to be satirized, humiliating them in front of their team members.

\section{Objectives}

The objectives of this study, therefore, were twofold.

1) To identify the existence of homosexual relationships between adolescent soccer athletes and their coaches, as well as to analyze the symbolic representations of these relationships;

2) To understand the intention behind homoerotic relationships (i.e., sexual attractions between members of the same sex) that are established between members of the administrative staff and the soccer players during their participation in youth leagues.

\section{Methodology}

The methodological approach used to develop this study was based in qualitative and exploratory research and grounded in the literature of sport psychology, social psychology, sociology, and the psycho-sociology of sport and physical education (Thomas \& Nelson, 2002).

Our study was grounded in an interpretive paradigm, because we sought not one, but the many truths that the voices of various individuals can provide (Weed, 2009). For example, as Stake noted, quantitative studies that use positivist frameworks hope to "answer specific questions about a small number of variables, while qualitative research seeks to answer broader, open-ended questions" (Stake, 1995).

Braun and Clarke $(2006,2013)$ suggested that the data analysis, based on a qualitative and interpretative perspective, should encompass a broad view of the data. The use of reports of experiences, social representations, and social phenomena in different contexts promote flexibility in the analysis of the collected material.

We used the life history method (Queiroz, 1988), with the participation of former professional athletes and still active adolescent athletes. The life history method is not concerned with the number of research subjects, but with the manner in which data are collected and the quality of the samples. Here, we attempted to record the experiences of several individuals within the same community, as Queiroz (1988) suggested.

A "life history," explained Vieira (2001), is, by definition, the speaker's account and an attempt to reconstruct the events he has experienced. These facts, whether appearing to be significant or not, allow researchers to establish relationships between the members of a group and their profession, and their social status, values, habits, and attitudes.

In this study, the groups being investigated were soccer teams and the group members playing or working in these environments, such as athletes, coaches, directors, agents, advisors, trainers, doctors, or support staff. These particular individuals were chosen because they had already worked with the researcher in other capacities, and were interested in participating in the study by providing their life histories. Campbell and Machado (2013) remind us that the researcher's relationship with his or her participants should be revealed, as this can have an impact on the results of the study.

The categories for analysis emerged from the selection of small parts of the participants' dialogues (narratives). These fragments were chosen because of their apparent relevance to the study's research questions, and were subjected to thematic analysis as explicated by Braun and Clarke (2006, 2013). The resulting themes were then subjected to further analysis based on the theoretical concepts of discourse analysis (Orlandi, 2010; Pêcheux, 2009). In the life story method of inquiry, the meaning of the story, and, hence, the most appropriate theory from which to frame the interpretation of the story, will "flow from the story itself" (Atkinson, 1998).

This investigation was performed in accordance with Resolution No. 196, October 10, 1996, and was approved by our university's Ethics Committee. All documents, statements, and terms of consent were completed and filed in accordance with regulation CEP/FAMERP, \# 001-004121/2011, and funded by CEP \# 333/2011.

\section{Participants}

Inclusion criteria included: Athletes who were tied to a professional soccer club, and have played for, or currently were playing on, a team that participates in official championships organized by sport federations. They must have previously played in or been involved in the sport, or were currently playing in or involved in the sport.

The study was not limited to only one age group, but included younger athletes as well as those who had already ended their careers. As Queiroz (1988) observed, "The transmission of experiences or stories can tell us as much about the everyday facts of our distant past as they can about the everyday facts of our recent past"' (p. 16).

Six individuals participated in the study, including three adolescent athletes, ages 14,15 , and 16, and three former athletes, ages 26, 28 and 45. In order to preserve their identities in the interview transcripts we referred to participants as speakers. 
We found it appropriate to interview a total of six participants, in adherence with a procedure described by Braun and Clarke (2013). They argued that the collection process is complete when the researcher observes that the data are completely saturated; that is, participants' responses become redundant.

Patton (2005) claims that the semi-structured interview makes it easy for the researcher to approach the participant, as well as helping to establish trust. It allows interviewees to talk about complex and sensitive matters, while provoking spontaneous and sincere answers. Vieira (2009) and Köche (2002) suggest that this data collection instrument can be ideal when participants are queried about the affective aspects and personal meanings of attitudes and behaviors.

A single interviewer posed semi-structured questions to each of the participants, and their responses were tape-recorder using a single tape recorder. These responses were then transcribed to a digital word-processing program, MSWord. The questions the interviewers used to guide the participants were:

1. What are some of the difficulties you faced in trying to adapt to the world of soccer? What was your experience like at the beginning of your soccer playing career?

2. What are some of the personal and professional relationships you have had - those that involve athletes, coaches, directors and supporters - that occur inside of the locker rooms?

3. How do you view the transactions that occur in the sports market, especially the financial, professional, and emotional ones? What about concessions, bargains, and harassment involving soccer players?

4. How do you see the role of the coach as it relates to the athlete's career, to the team's performance, and to his control of players' actions?

\section{Data analysis}

The researchers analyzed the transcribed statements, which produced data that fit into dominant categories, or themes (Ausubel, 1993; Braun \& Clarke, 2006; Forghieri, 2001; Orlandi, 2010; Pêcheux, 2009), and which we interpreted as "truths." That is, they are the themes that recurred throughout the "community" (Queiroz, 1988) of soccer players in our study. The dominant themes that emerged, then, were: 1) The coach-athlete relationship as mediated by sexual harassment; 2) The body as currency in the intense game of exchange; 3) Vulnerability on the field; and, 4) Homosexual relations and moral development.

\section{Results and Discussion}

\section{The coach-athlete relationship as mediated by sexual harassment}

It is a challenging task to investigate individuals who disclose personal information about their sexuality and affections. It is especially difficult when their sexuality and affections are considered taboo - a taboo that has been socially, historically, and culturally constructed through dogma, prejudice, stigma, discrimination, and exclusion. For instance, in the sports environment, where sexual harassment or other forms of coercion occur, such behaviors are commonly covered up by "boleiro" culture in order to ensure the maintenance of male stereotypes.

For certain professionals - in this case, soccer players, for example, sexuality can be an embarrassing subject, because, in sports culture, soccer players are supposed to possess stereotypical male attributes: masculinity, courage, physical stamina, domination, and strength. The world of soccer, then, is an unusual and unlikely place for overt homosexuality, because the stereotypical attributes of homosexuality are dichotomously opposite to those of heterosexuality. They include effeminacy, timidity, physical weakness, and submission (Machado, 2002; Poczwardowski, Barott, \& Peregoy, 2002; Rosa, 2008; Whitson, 1990).

Thus, difficulties arose when the researchers addressed this issue, when the speaker began to express feelings and emotions that may have lain dormant for many years, either due to the participants' lack of motivation to explore them, or because they didn't want to revive "old wounds" that had begun to heal. Discussing their sexuality proved to be an encounter that was permeated by fear, jealousy, hesitation, and arousal, all while they simultaneously felt the anguish and relief provided by the opportunity to vent about the moral and emotional dilemmas that occur in sports.

The participants' life histories revealed personal experiences in which the coach-athlete relationships occasionally were marked by sexual harassment, and, more specifically, by homosexual relations that occurred between the coach and athlete in youth leagues.

At times the interviews exposed affective or erotic sexual involvement between coaches and athletes, which occurred on a day-to-day basis in the soccer team's lodging facilities. This type of relationship also sometimes occurred with other members of the management team.

We noted a considerable incidence of merely homoerotic relationships as opposed to affective relationships between athlete and coach or athlete and a member of the technical committee or director, perhaps due to the high turnover of young people in these environments. Homoerotic relationships, here, are defined as those characterized by a temporary sexual attraction. Dias (2014) defines homoaffective relationships as those that occur between two people of the same sex, stably, regularized by the new laws on gay marriage, strengthened by love and affection. This is the definition used in this study. However, it should be noted that others (Costa, 1992; Kronka, 2003; Paiva, 2006; Souza, 2010) argue that all homosexual relations are homoerotic, because some people of the same sex seek a relationship just for pleasure, eroticism, and for the fleeting satisfaction of sexual desires. They ask, aren't these relations-characterized by stealth and not publicly revealed, and which occur in places exclusively dedicated to such meetings-homoerotic?

Other aspects that stimulate homoerotic exchanges (consensual or those that constitute sexual harassment [coerced]) in our study of soccer players are associated with the physical proximity afforded by changing rooms, the aesthetic presentation of the young body (Graça \& Lacerda, 2011), the desire of adolescents to 
be part of the team, the emotional needs of the coach or manager, the use of power by the coach as an exchange currency for the team draft, and perhaps the self-satisfaction of these adolescents in being able to maintain this form of sexual relations. However, the "packaging," or framing (Goffman, 1974; Graça \& Lacerda, 2011), of the product (athletic and perfect body) awakens the desire for consumption, as can be seen in the narrative of Speaker 5:

[...] that's it, a sexual relationship. The person wanted you to have sex with him so that I... you could be on a better team or even be drafted into a selection. [...] It was a more intimate involvement, you know. I had to have a sexual relationship, sometimes with ... with the coach.

It also seems interesting to note in this account the change of speech from the first to the second person: "[...] The person wanted you to have sex with him so that I [...] you could be on a better team [...] (Speaker 5)." This transition appears to mark the moment in which the speaker tries to save face and not compromise his heterosexual self-image. One of the justifications the respondents gave for why sexual harassment occurs more frequently with youth athletes and to a lesser degree with professional athletes is that in this phase the adolescent goes through a period of instability, including financial instability. This facilitates a type of harassment that occurs by means of the exchange of sexual favors for material goods: clothes, accessories, gifts, and dinners, among other promises. "[...] this kind of harassment happens all the time in youth leagues, usually with teenagers, [...] the kid that lives in the housing, and that... is harassed, he goes for the financial promises, for the gifts" (Speaker 6).

Bauman $(2008,2011)$ argued that with this type of exchange, the relationships are not secured, but are instead presented like fast-food culture: fleeting, transient, and revealing of a postmodern society. The morals and ethics of the sport directly correspond with what society adopts as the norm. Therefore, as Bauman argued, changes occur in accordance with the need to adapt to the historical moment, and in this case, with a volatile, fleeting, and liquefied profile.

For this theme, "The coach-athlete relationship as mediated by sexual harassment, " it is possible to detect that the intimacy of the locker rooms, the shield of the sports institution, and the cult of the body are contextual and temporal conditions that contribute to the adolescent's acceptance of homoerotic relationships and sexual harassment, and to his belief that he must submit to the power and authority of the coach. His vulnerability during this process facilitates the action of the coach and the mutual satisfaction of desires - sexual and professional. This "contract" benefits both coach and athlete. On the one hand the coach satisfies his erotic desire, and on the other the athlete's dream of achieving professional status and stardom is kept alive.

\section{The body as currency in the intense game of exchange}

Indeed, homosexual relations can play a commercial role when a player is trying to achieve his professional goals. These relationships occur not only with members of the management team, but, also, with other participants involved in the soccer youth leagues, like directors, agents or others:

[...] during the period when I was a soccer player, I received several proposals to do that... [...]. Many athletes I hung around with ended up doing that, going out with those people, and after they were drafted in several selections, they were placed at various clubs" (Speaker 5).

This practice becomes even more evident when another speaker mentions in his story that:

[...] after I left the team, we really saw who he 'got along' with best... After this case, he still harassed a boy on the team and had sex with him, and after I left the team [...] I was kicked off the team, without any kind of compensation (Speaker 3).

These affairs are, therefore, marked by purely physical and erotic interests, where the body represents a bargaining chip, devoid of the affective components in permanent and lasting relationships. Canevacci (2008) argued that, since this productthe body - is erotically exposed in locker rooms and marketed on billboards and in the media, it remains, for those with a fetish to "consume" the body, as an object of desire.

The narratives provide evidence not only of sexual involvement, but also reflect a certain naiveté in the athlete, who believes his active participation in such relationships do not compromise his masculinity. This naiveté seems to help "preserve" his heterosexuality.

We observed in the speakers' stories that homosexuality represents a one-way street, one in which only the coach - as the "passive" agent of the relationship, is considered homosexual, and that the other participants, even though they are the "active" agents in the relationship, are hailed as manly. There is a need for participants to clearly mark the distribution of these roles in the group:

[...] from where I stood it was the coach who was homosexual $[. .$.$] the coach received the athlete as the active$ one [...] who accepted the blackmail of the coach and ended up going (being accepted) in order to have more 'status' on the field (Speaker 4).

Thus, the speaker reinforced the idea that, in theory, the athlete continued his heterosexual saga, because in his view only the coach behaved as a homosexual. It may be that any sacrifice, including their own submission, is worth it to these athletes in order to gain entrance to and remain in this space, the environment of professional soccer. They believe that they need to provide sexual favors to others of the same sex, and they see these transient relationships as having no effect on their masculinity.

This may occur, also, because, according to Aberastury and Knobel (1986), occasional circumstantial homosexuality exists. It is possible that a player's identity and personality may be strengthened via these discoveries in this time of adolescent sexuality through the act of confronting conflicting feelings about homosexuality. 
Such relationships commonly occur between members of same-sex groups, in places in which young people coexist for long periods of time, such as boarding schools, prisons, military groups, or sports teams (Anderson, 2013; Machado, 2002, 2006).

Such relationships often act to boost sexual satisfaction or relieve sexual tension rather than to establish loving relationships. When such participants have been satisfied, they begin to once again demonstrate heterosexual behaviors, leaving the homosexual experience in their past (Aberastury \& Knobel, 1986).

Because young soccer players are in transition from adolescence to adulthood, they still face the need to resolve emotional and moral conflicts regarding the trade of sex with males: "He was a coach of another category, you know [...] he had a lot of 'moral' \{influence\} [...] and since I was housed [...] if I were to have lunch at his house over the weekend ... he would help me [...]" (Speaker 1).

These narratives in the theme, "The body as currency in the intense game of exchange," reflect the adolescent athlete's ability to use his body to achieve professional goals. In this game of erotic exchanges there is no concern with the moral or emotional issues that may arise from these agreements, but only for one more imagined chance to achieve success in this environment of extreme competition. In this context, it is worth everything to achieve success, and the actors understand homosexual relations as a passing phase, one that does not compromise future heterosexual life.

\section{Vulnerability on the field}

With the exception of a few first-league soccer teams (Cruz, 2012), the majority of soccer teams in Brazil practice at low technical and economic levels. They do not have the financial resources to provide good working conditions for young players (Alvito, 2006; Silva \& Campos Filho, 2006).

Training programs for young athletes, including youth and junior categories, frequently have improvised installations, without decent living conditions, healthy food, material for training, psychological and social support, school monitoring, and decent salaries (Mósca, Silva, \& Bastos, 2009). As one young player revealed:

The accommodation I lived was under the bleachers of the stadium [...]. It is very difficult to live with different people ... guys who do not have ... no affinity ... not have an intimacy ... you're far away from family ... of a play without some affection ... getting anything ... so many leave ... (Speaker 4)

These poor work conditions seem to expose the adolescent athlete, leaving him vulnerable. When a young player finds himself in this state of social vulnerability, economic and psychological factors can facilitate the occurrence of sexual assaults or sexual harassment:

[...] I had a friend once who accepted one of those proposals ... [...] I ... came to São Paulo ... the coach that brought me, he had already come onto me ... had already tried to ... it ... he tried to get me to go to bed ... it's just that I had just never thought of it ... [...] (Speaker 2).
For the adolescent athlete who agrees to participate in sexual activities (through physical need, or due to financial or social ambition), the coach can, among other things, ensure a place on the team: "[...] this happened with a teammate we he had there in my hometown [...] he was involved with the coach, you understand? He did some stuff there, obscene..., then the coach took him to play in the title game [...]" (Speaker 3).

Other reports revealed how some coaches sexually harass young athletes in the youth leagues, taking advantage of their social, economic and emotional instability. For example, the coach preys on the immaturity of the boys:

[...] this will happen everywhere. Especially in the basic soccer categories ... where the boy spends too much time alone, especially ... when the coach indicates a club for him to play in professionally, promotes him for the National teams ... so they are ingenuous and accept the coach's sexual advances (Speaker 4).

Too, the sexual aggressors sometimes use media coverage as a tool for control. The official competitions of the basic categories do not receive the same media coverage as do the professional teams. Therefore, athletes and their stories go unnoticed by the general public (Alvito, 2006; Silva, 2006). Taking advantage of this, some members of the technical committees and managers feel protected by anonymity and feel free to explore intimate situations.

[...] this kind of harassment happens a lot on basic soccer teams, usually with teenagers. The athlete who is professional, who already has his salary, is already successful, does not need it [...] the boy who lives in the housing, and who is harassed, he will buy the financial conditions, buy the gifts ... So why is this kind of person looking more for teenaged guys to harass, boys who live in the housing ... Because the guy, when he is on the professional team, no longer needs this, he has his salary, he's in the media all the time, right ... [...], then it is easier for the coach or manager to approach a guy without a personality ... than a professional who is already well-paid, who is already in the media (Speaker 6)

Other players' perceptions of these relationships seem to be associated with sexual exploitation and prostitution. They suggest that sexual favors are somehow part of a financial transaction:

This particular player [...] ... because the coach sought this player at his house ... saw that the financial situation was bad ... saw the poverty of the family ... Then he makes a lot of promises to allure the boy ... after the boy arrives at the club, the coach ... helped with some food, invited him to dinner, paid for pizza ... gave him designer clothes ... new tennis shoes ... So, the boy was always there ... not only $[\ldots]$... as an athlete, but as a sexual object ... (Speaker 4).

[...] Then the boy is amazed by all of this, and, then, when it happens ... the harassment by older people who have more experience (Speaker 6). 
This participant appears to live as if he were a sex slave to the extent that, weakened by socioeconomic conditions, he was subjected to comply with any role as a means to survive and to stay in the group:

[...] It's difficult to talk about ... but the player is ... is ... sexually "induced," exploited ... [...] If he does not do what the coach wants $[. .$.$] an example ... ahh ... is asking the player have sex$ with him ... to 'eat' the coach, he can be excused from the club. The coach will claim technical defect, but we know that is not true ... And to continue the dream of being a rich and famous player, the boy submits to this blackmail ... like a slave ... that he is there to satisfy the boss's desires ... (Speaker 4).

$[\ldots]$ they (the guys) want to achieve a goal ... they still failed. So they are corrupted (Speaker 6).

In this situation, the perpetrator begins to offer incentives during a player's adolescent phase as a way to demonstrate that having a relationship with him can offer rewards. The perpetrator takes advantage of moments of vulnerability, the result of changes in the player's life such as leaving his parents' home, discovering his sexuality, needing to ensure his male status, or even simply not knowing how to not agree to play this game with an authority figure.

Pêcheux (2009) claimed that the strength of this discourse is the dialectical relationship between the subject and history, context, and ideology. Therefore, it is the coach's authority that constructs a hierarchical relationship of power within the group, and, in many cases, contributes to the formation of rules and the blind obedience of individuals within the group. In this case, submission gives way to persuasion, which may be due to the perpetrator's charisma, but is mostly due to an ideological situation of domination and power.

Within this theme, "Vulnerability on the field," it was revealed that the time a young soccer player spends on a basic team can be marked by tensions, personal conflicts, fear, guilt, and shame. This framework of social and psychological vulnerability - in athletes who seek to realize the dream of becoming rich and famous players at any cost - provides an opportunity to some coaches or professional authorities to blackmail them. In that moment the athlete understands the strength of the "laws of the locker room," built and maintained on his doubt. Such emotional situations will help to configure the social representations that will shape their adulthood.

\section{Homosexual relations and moral development}

Still other emotional nuances are generated by these homosexual relationships. These situations require a maturity from the adolescent in order to manage feelings that typically shape their moral development, such as jealousy, envy, affection, intrigue, fear, guilt, and shame (Araujo, 2003; Harkot-De-LaTaille, 2003). As Speaker 2 revealed:

He said that ... if I ... if I did everything he asked me, I would already be on a major team ... I had passed the tryout. Only this coach [that brought me to São Paulo] was gay, and he found out that the coach from [where I passed the tryout] was also gay, so he did not let me stay there ... it seems that he was jealous $[\ldots]$.

Here, this player learns the first lessons of his new environment, which are loaded with rules and regulations that are different from those which he has known from his family, school, and church.

Some parts of the stories characterize the difficulty of assimilation, and both practical and psychological conflict resolution. " $[\ldots]$ he also made this proposal to a friend of mine that came along [...] so if I had been there ... maybe I could have been on a major team ..." (Speaker 2).

Whether the player becomes involved in either of the two possible situations-- accepting or not accepting the sexual advances, the resulting situation poses a moral dilemma and creates conflict. In just the fact that such a choice exists, the emotional breakdown has already been established and the levels of anxiety, anguish, and stress increased (Machado, 1998, 2002).

The balance of impulses in these relationships seems to stem from the athlete's need to comply with socially accepted moral values and to suppress the urge to give in to that which does not conform to social structure (Boock, Furtado, \& Teixeira, 2002; La Taile, 2006).

In these situations, the athlete may feel guilty for not having accepted the harassment, and thus not being in a privileged position; or, he may feel guilty for accepting it, and realizing only afterwards that he was mistaken. Guilt, in this context, as Araújo (2003) argued, can be constituted as a point of equilibrium, derived from the repression of desires to maintain order within a particular organization.

In any case, these struggles seem to be major components of group functioning, and blame is an element that interferes with (or, mediates) these relationships. Players' denials of participation in same-sex relations could be interpreted as a criticism of people who do participate, a defense mechanism proposed by Freud (Bock et al., 2002). This defense mechanism, called projection, stems from an individual's need to criticize an action in which he or she unconsciously wants to participate.

Additionally, practicing "self-defense" via participation in homosexual relations could tarnish a player's image as a masculine heterosexual athlete or put him in an embarrassing situation, often associated with religious dogma. Within the context of some religions, for example, it is inconceivable that a man would approach another man for the purpose of having sex. The invocation of God as a means of protecting against this type of conduct represents, to some extent, the need for individuals to live according to the rules and values practiced by the dominant society, and, in particular, by institutions that govern it, like the church (Araújo, 2003; Brown \& Lunt, 2002; Deleuze \& Guattari, 2009).

It seems, still, that other team members and professionals (i.e., players, trainers, director, and advisors) practice what might be considered a veiled acceptance of these behaviors in order to preserve the status-quo. There is, in essence, a culture of silence: everyone knows about these practices, but prefers to stay silent. The disclosure of homosexual practices in the game 
of football could damage the public image of this sport, which is defined by stereotypes of aggression, virility, and strength. The discussion of homosexuality in any context, it seems, is taboo. Players such as Robbie Rogers and Thomas Hitzlsperger, who "came out" only after their playing careers ended, exemplify this phenomenon (Christenson, 2014; McRae, 2013).

Perhaps another explanation for this type of silence amongst team members is the need to ensure that the whole group, or team, continues to produce results. Cohesion and harmony depend on the absence of conflict (Weinberg \& Gould, 2001); therefore, the cover-up of homosexual behavior presumably contributes to team unity, and, therefore, to its victories.

Under the theme, "Homosexual relations and moral development," the players experienced ambivalent sentiments that represent guilt, consequence, punishment, and judgment. In this environment, such sentiments work as markers of morality, but they are fleeting, relative, and practiced when convenient (Araujo, 2003; Bauman, 2011; Bredemeier \& Shields, 1998; La Taille, 2010). These feelings need to be kept in check so that the smooth operation of the team can be ensured. For example, silence, associated with conduct that protects the coach in relation to the group or himself, can alter the emotional states of adolescents, increasing group anxiety and inducing self-harm or aggression (Bach \& Goldberg, 1978).

\section{Conclusion}

The objectives of this study were: 1) to analyze the existence and symbolic representation of homosexual relationships between adolescent soccer players and their coaches, and, 2), to understand the intention behind homoerotic relationships that are established between members of administrative staff and the soccer players during their participation in youth leagues.

With regard to the first objective, by disclosing parts of their life histories, the participants - both athletes and former athletes - revealed participation in sexual acts with athletes from youth leagues and members of the management team. The homosexual relationships reported by subjects in this study occurred in different contexts, in various places and situations, and happened between the coach and the adolescent athletes as part of an agreement between them. In some cases, they occurred in order for the subject to secure permanence on the team.

Sexual compensations in this case, are resolved on the basis of sexual harassment bias, by setting a symbolic representation of power in order to define the roles in the group (Anderson, 2013; Hargreaves \& Anderson, 2014). The erotic nature in this form of engagement contributes to temporary, ephemeral relationships without lasting emotional bonds that could characterize stable homo-affective relationships.

It is true that managers and coaches have favorite players, based on their playing performance, not on sexual preference or sexual performance. Clearly, the world of soccer does not revolve solely around sexual innuendo and the activities described by the participants in this study. Too, our findings cannot be generalized to all sporting contexts.

In these cases, the incentives that the coaches offered to win the confidence of the young players, and, subsequently, to receive sexual favors, culminated in the promise of professional success. However, this erotic and deceptive game created by the coach does not seem to depend on developing intimate relationships with the players. Rather, the athletes complied with their respective coaches only to the extent that they were required in order to establish or maintain their "contract."

The arguments to win the adolescents' trust that were used by managers or others to get sexual favors in return appeared in the form of promises of a successful career, or, perhaps being selected for a team, getting a transfer to a national major category team, for example. They also offered material things such as money, clothes, and jewelry, among other items

With regard to the second objective of this study, the coach's behavior helped to illuminate the "intentionality" of emotional relationships that are established between components of the technical staff and the soccer players. However, this elusive and erotic game that the coach creates appears not to depend on affective relationships. The athlete only becomes an accomplice to the coach or manager in an attempt to establish a contract with him. He imagines that he can become famous, a winner, and a hero. This "contract" has great social significance.

On his own, the athlete cannot fully achieve social success, celebrity, and hero-like status. The coach and his teammates represent the "package" necessary for his personal and professional growth. In this regard, the ongoing pressures placed upon athletes to achieve professional success help to contribute to their submissive position in relation to a coach's power and authority. Thus, the teenagers allow themselves to be subjugated in order to achieve their goals.

Affective, professional, experiential, and emotional exchanges in soccer youth leagues often may culminate in sexual exchanges. Therefore, these situational elements represent "knowledges" that these young athletes will need to acquire in order to successfully participate in these groups.

We can imagine, then, that conflicts will arise, based on the emergence of players' ambiguous feelings. The coach is the paternal archetype; therefore, the athlete cannot positively connect with him if at one moment he is the coach's "son," being groomed for success and performance at a professional level, and, in the next moment, the coach molests him.

In this sense, the young player cannot allow himself to feel sexually desired by another person of the same sex, especially if this person tends to exercise paternal power (Graça \& Lacerda, 2011; Souza, 2010). Such feelings are not compatible with the idealized attributes for the soccer player, who must be a man, that is, "masculine" and straight.

Hence, the "game" continues, leaving young players in the position of trading sexual favors for promises of success. This challenges players' sense of moral correctness and leaves them emotionally vulnerable. We do not suggest that this "game" pervades the entire sporting environment. However, our findings suggest that the effects of this practice are profound, and deserve further investigation, perhaps with other soccer players and with athletes involved in other sporting environments. This behavior is closely related to the maintenance of moral and social values, and in some cases, can mean the exclusion or 
non-participation in this world of possibilities that soccer (and other sports) provides.

\section{References}

Aberastury, A., \& Knobel, M. (1986). Adolescência normal, um enfoque psicanalítico ( $5^{\mathrm{a}} \mathrm{ed}$.). Porto alegre: Artes Médicas.

Anderson, E. (2013). Sport, Masculinities, Sexualities - Anderson. New York: Taylor \& Francis.

Anderson, E. (2005). In the Game: Gay athletes and the cult of masculinity. State University of New York. Retrieved August 31, 2014, from http://books.google.com.br/books?id=GD-ukhQ-w$4 \mathrm{gC} \&$ redir_esc $=\mathrm{y}$.

Alvito, M. (2006). "A parte que te cabe neste latifúndio:" O futebol brasileiro e a globalização. Análise Social, 179, 451-474. Retrieved September 06, 2014, from http://www. scielo.gpeari.mctes.pt/scielo.php?script $=$ sci_arttext\&pi$\mathrm{d}=$ S0003-25732006000200007\&lng=pt\&tlng=pt.

Araújo, U.F. (2003). Conto de escola: A vergonha como um regulador moral. São Paulo: Moderna/Campinas: Editora da UNICAMP.

Atkinson, R.L., Atkinson, R.C., Smith, E.E., Bem, D.J., \& Hoeksema, S.N. (2002). Introdução à Psicologia de Hilgard (13 $3^{\text {rd }}$ ed.) (pp. 370-668). Porto Alegre: Artmed.

Atkinson, R. (1998). The life story interview. Thousand Oaks, CA: Sage Publications.

Ausubel, D. (1993). Teoria da aprendizagem significativa. Porto Alegre: Manole.

Bach, G.R., \& Goldberg, H. (1978). Agressividade criativa. Rio de Janeiro: José Olímpio.

Badinter, E. (1993). XY: Sobre a identidade masculina. Rio de Janeiro: Nova Fronteira.

Bandura, A. (1977). Social learning theory. New Jersey: Prentice Hall.

Bauman, Z. (2008). A sociedade individualizada: Vidas contadas e histórias vividas. Tradução José Gradel. Rio de Janeiro: Zahar.

Bauman, Z. (2011). Vida em fragmentos: Sobre a ética pós-moderna. Tradução Alexandre Werneck. Rio de Janeiro: Zahar.

Betti, M. (1991). Educação Física e Sociedade. São Paulo: Movimento.

Bock, A.M.B., Furtado, O., \& Teixeira, M.L.T. (2002). Psicologias, uma introdução ao estudo de psicologia (13 ${ }^{\mathrm{a}}$ ed.). São Paulo: Saraiva.

Bozon, M. (2004). Sociologia da sexualidade. Rio de Janeiro: FGV Editora.

Braun, V., \& Clarke, V. (2006). Using thematic analysis in psychology. Qualitative Research in Psychology, 3, 77-101.

Braun, V., \& Clarke, V. (in press, 2013). Successful qualitative research. A practical guide for beginners. London: Sage.

Bredemeier, B.J.L., \& Shields, D.L.L. (1998). Moral Assessment in sport psychology. In J.L. Duda (Ed.), Advances in sport and exercise psychology measurement (pp. 257-276). Morgan Town, WV: Fitness Information Technology.

Bronfenbrenner, U. (2011). Bioecologia do desenvolvimento humano: tornando os seres humanos mais humanos. Trad. André de Caralho-Barreto. Porto Alegre: Artmed.

Brown, S.D., \& Lunt, P. (2002). A genealogy of the social identity tradition: Deleuze and Guattari and social psychology. British Journal of Social Psychology, 41, 1-23.

Campbell, D.F., \& Machado, A.A. (2013). Ensuring quality in qualitative inquiry: Using key concepts as guidelines. Motriz: Revista de Educação Física, 19, 572-579. Retrieved September 15, 2014, from http://www.scielo.br/scielo.php?script=sci_arttext\&pid=S1980-65742013000300007\&lng=en\&tlng=en. $10.1590 /$ S1980-65742013000300007.
Canevacci, M. (2008). Fetichismos Visuais - Corpos Erópticos e Metrópole Comunicacional. São Paulo: Atelie Editorial.

Cerqueira, E.K. (2011). Sentido da Sexualidade Humana. In E.K. Cerqueira (Ed.), Sexualidade, Gênero e Desafios Bioéticos (pp. 71-128). São Caetano do Sul-SP: Difusão Editora.

Christenson, M. (2014). Thomas Hitzlsperger announces he is gay in newspaper interview. The Guardian. Retrieved August 31, 2014, from http:/www.theguardian.com/football/2014/jan/08/thomas -hitzlsperger-gay-announces-homosexual

Costa, J. F. (1992). A inocência e o vício: estudos sobre o homoerotismo. Rio de Janeiro: Relume-Dumará.

Cruz, R.M. (2012). A formação de atletas de futebol: um estudo na categoria sub-15 do Cruzeiro Esporte Clube, Belo Horizonte-MG. Revista Brasileira de Futsal e Futebol, 4, 189-194. Retrieved August 31, 2014, from. http://oaji.net/articles/900-1401190952.pdf

Deleuze, G., \& Guattari, F. (2009). Anti-Oedipus: Capitalism and Schizophrenia, $6^{\text {th }}$ ed. New York: Penguin Classics.

Del Percio, E. (2012). Futebol, Dança e Unasul, ou uma crise do "ego forte" da modernidade. In L. Rohden, M.A. Azevedo, and C.C. Azanbuja (Eds.), Filosofia e Futebol: troca de passes (pp. 95-103). Porto Alegre: Sulina.

Dias, M.B. (2014). Homoafetividade e os Direitos LGBTI (6 $6^{\mathrm{a}}$ ed.). São Paulo: Editora dos Tribunais.

Fávero, M.H. (2010). Psicologia do Gênero: psicobiografia, sociocultura e transformações. Curitiba: Editora UFPR.

Forghieri, Y.C. (2001). Psicologia Fenomenológica: fundamentos, métodos e pesquisas. São Paulo: Pioneira.

Foucault, M. (1987). O combate da castidade. In P. Ariès and A. Béjin (Org.), Sexualidades ocidentais (pp. 25-38). São Paulo: Brasiliense.

Foucault, M. (1988). História da Sexualidade I: a vontade de saber. Rio de Janeiro: Graal.

Franco Junior, H. (2007). A dança dos Deuses: Futebol, Sociedade, Cultura. São Paulo: Cia das Letras.

Gianmi, A. (1998). Representações e Sexualidade: Psicologia Social e Pluridisciplinaridade. In M.A. Loyola (Org.), A sexualidade nas ciências humanas (pp. 201-225). Rio de Janeiro: EdUERJ.

Giulianotti, R. (2002). Sociologia do futebol: Dimensões históricas e socioculturais do esporte das multidões. São Paulo: Nova Alexandria.

Goffman, E. (1974). Frame Analysis: An Essay on the Organization of Experience. New York, NY: Harper \& Row.

Graça, L.G., \& Lacerda, T.O. (2011). Da estética do desporto à estética do futebol. Revista Brasileira de Ciências do Esporte, 33, 427-444. Retrieved September 05, 2014, from http://www.scielo.br/scielo.php?script=sci_arttext\&pi$\mathrm{d}=\mathrm{S} 0101-32892011000200010 \& \operatorname{lng}=$ pt\&tlng $=$ pt. 10.1590/ S0101-32892011000200010.

Hanna, J.L. (1999). Dança, sexo e gênero: signos de identidade, dominação, desafios e desejos. Rio de Janeiro: Rocco.

Harkot-De-La-Taille, E. (2003). Ação moral e estereótipos culturais. In V.A. Arantes (Ed.), A afetividade na escola: alternativas teóricas e práticas (pp.171-190). São Paulo: Summus.

Hargreaves, J., \& Anderson, E. (2014). Routledge Handbook of Sport, Gender and Sexuallity. New York: Routledge International.

Heilborn, M.L., \& Cabral, C.S. (2013). Youth, gender and sexual practices in Brazil. Psicologia \& Sociedade, 25, 33-43. Retrieved January 07, 2014, from http://www.scielo.br/scielo.php?script=sci_arttext\&pid=S0102-71822013000500005\&lng=pt\&tlng=en. $10.1590 / \mathrm{S} 0102-71822013000500005$

Heilborn, M.L., Duarte, L.F.D., Peixoto, C., \& Lins de Barros, M. (2004). Sexualidade, família e ethos religioso. Rio de Janeiro: Garamond/CEPESC.

Heilborn, M.L. (2006). Entre as tramas da sexualidade brasileira. Revista Estudos Feministas, 14, 43-59. Retrieved January 08, 
2014, from http://www.scielo.br/scielo.php?script=sci arttext\&pid=S0104-026X2006000100004\&lng=pt\&tlng=pt. $\overline{10.1590 /}$ S0104-026X2006000100004

Helal, R., Lovisolo, H., \& Soares, A.J.G. (2011). Futebol, Jornalismo e Ciências Sociais: Interações. Rio de Janeiro: EdUERJ.

Kehl, M.R. (2003). As Máquinas Falantes. In A. Novaes (Org), $O$ homem-máquina: a ciência manipula o corpo (pp. 243-259). São Paulo: Companhia das Letras.

Köche, J.C. (2002). Fundamentos de metodologia cientifica: teoria da ciência e iniciação à pesquisa (20 ${ }^{\text {nd }} \mathrm{ed}$.). Petrópolis/RJ: Vozes.

Kohlberg, L. (1992). Psicología del Desarrollo Moral. Bilbao: Editorial Desclée de Brouwer.

Kronka, G.Z. (2003). Corpo, desejo e poder: identidade e subjetividade no discurso (homo) erótico. Cadernos AEL, 10,153-181. Retrieved August 30, 2014, from http://segall.ifch.unicamp.br/publicacoes ael/index.php/cadernos ael/issue/view/5/showToc

Lahn, P. (2010). Der feine Unterschied: Wie man heute Spitzenfussballer wird. Munich: Betascript Pub.

La Taile, Y. (2006). Moral e Ética: dimensões intelectuais e afetivas. Porto Alegre: Artmed.

La Taille, Y. (2010). Moral e Ética: Uma Leitura Psicológica. Psicologia: Teoria e Pesquisa, 26, 105-114.

Machado, A.A. (1998). Interferência da torcida na ansiedade e agressividade de atletas adolescentes. Tese de Livre Docência. Instituto de Biociência, Universidade Estadual Paulista, Rio Claro/SP.

Machado, A.A. (2002). Homem e esporte: o masculino nas inter-relações esportivas (n. 9, pp. 57). In: Anais do Congresso Brasileiro de Psicologia do Esporte. Jundiaí: Fontoura.

Machado, A.A., Presoto, D., \& Gouvêia, F.C. (2006). Esporte na perspectiva da teoria crítica. In A.A. Machado (Ed.), Psicologia do Esporte: da educação fisica escolar ao esporte de alto nivel (pp.258-266). Rio de Janeiro: Guanabara Koogan.

Machado, A.A. (2006). Psicologia do Esporte: da educação física escolar ao esporte de alto nível. Rio de Janeiro: Guanabara Koogan.

Machado, A.A., Gouvea, F.C., Bartholomeu, D., \& Moioli, A. (2008). Precocidade nos esportes: uma análise pouco agradável. In A.A Machado (Org.), Especialização Esportiva Precoce: Perspectivas atuais da Psicologia do Esporte ( $1^{\text {st }}$ ed.) (pp. 35-48). Jundiaí: Editora Fontoura.

Machado, A.A. (2011). O contexto esportivo aos olhos da psicologia do espore: relações com os fatores externos. In A.A. Machado and R. Gomes (Org.), Psicologia do Esporte: da escola à competição $\left(1^{\text {st }}\right.$ ed.) (pp. 249-268). Várzea Paulista-SP: Fontoura.

Mandard, S. (2003). Homossexualidade ainda é tabu no esporte: mulher assume com mais facilidade. Trad. Jean-Yves de Neuffville. Jornal Le Mond \{On Line\}. Retrieved December 26, 2003, from http://noticias.uol.com.br/midiaglobal/lemonde/ult580u988.jhtm

McRae, D., \& Rogers, R. (2013). Why coming out as gay meant I had to leave football. The Guardian, 29 march. Retrieved August 31, 2014, from http://www.theguardian.com/football/2013/mar/29/ robbie-rogers-coming-out-gay

Meroni, F. (2011). Identidade Sexual e ideologia de gênero. In E.K. Cerqueira (Ed.), Sexualidade, Gênero e Desafios Bioéticos (pp.171261) São Caetano do Sul-SP: Difusão Editora.

Mósca, H.M.B., Silva, J.R.G., \& Bastos, S.A.P. (2009). Fatores Institucionais e Organizacionais que afetam a gestão profissional de departamentos de futebol dos clubes: o caso dos clubes de futebol no Brasil. Revista Gestão e Planejamento, 10, 53-71. jan./jun. Retrieved September 03, 2014, from http://www.revistas.unifacs. br/index.php/rgb/article/viewArticle/575

Moscovici, S. (2001). Social representations: explorations in social psychology. New York: New York University Press.

Orlandi, E.P. (2010). Análise de Discurso: princípios e procedimentos $\left(9^{\text {th }}\right.$ ed.). Campinas-SP: Pontes.
Paiva, A.C.S. (2006). A conjugalidade homossexual no sistema de gêneros e para além: micropolíticas homoeróticas. Revista de Ciências Sociais, 37, 63-76. Retrieved March 07, 2014, from http:// www.rcs.ufc.br/edicoes/v37n1/

Patton, M.Q. (2005). Qualitative research and evaluation methods $\left(3^{\text {rd }}\right.$ ed.). Thousand Oaks: Sage Publications.

Pêcheux, M. (2009). Semântica e Discurso: uma crítica à afirmação do óbvio. Trad. Eni Puccinelli Orlandi (4 ${ }^{\text {th }}$ ed.). Campinas-SP: Editora da Unicamp.

Perelberg, R.J. (2013). Configurações Sexuais múltiplas. Revista Brasileira de Psicanalise, 47, 103-110.

Perelberg, R.J. (2007). Space and Time in Psychoanalytic Listening. The International Journal of Psychoanalysis, 88, 1473-1490.

Pimenta, C.A.M., \& Alabarces, P. (2000). Novos processos de formação de jogadores de futebol e o fenômeno das 'escolinhas': uma análise crítica do possível". Peligro de gol. Estúdios sobre deporte y sociedad en América Latina. Buenos Aires: Clacso, 75-97.

Poczwardowski, A., Barott, J.E., \& Peregoy, J.J. (2002) The Athlete and Coach: Their Relationship and Its meaning. Results of an interpretive study. International Journal of Sport Psychology, 33, 116-140.

Queiroz, M.I.P. (1988). Relatos orais: do “indizível” ao "dizível." In O.M.V. Simson (Org.), Experimentos com histórias de vida (pp. 14-43) (Itália-Brasil). São Paulo: Vértice.

Rapaport, C.R., Fiori, W.R., \& Davis, C. (2007). Teorias do Desenvolvimento: conceitos fundamentais. São Paulo: EPU.

Rios, L.F., Parker, R., \& Terto Junior, V. (2010). Sobre as inclinações carnais: inflexões do pensamento cristão sobre os desejos e as sensações prazerosas do baixo corporal. Physis: Revista de Saúde Coletiva, 20, 195-217. Retrieved January 07, 2014, from http://www.scielo.br/scielo.php?script=sci_arttext\&pi$\mathrm{d}=$ S0103-73312010000100011\&lng=pt\&tlng=pt. 10.1590/S010373312010000100011.

Rodrigues Filho, M. (2003). O Negro no Futebol Brasileiro (4a ed.). Rio de Janeiro: Mauad.

Rodrigues, G.A. (2010). Pedagogias queer e libertária para educação em cultura visual. Educação e Pesquisa, 36, 735-745. Retrieved January 07, 2014, from http://www.scielo.br/scielo.php?script=sci_arttext\&pid=S1517-97022010000300006\&lng=pt\&tlng=pt. 10.1590/S1517-97022010000300006.

Rohden, L., Azevedo, M.A., Azanbuja, C.C. (2012). Filosofia e Futebol: troca de passes. Porto Alegre: Sulina.

Rosa, M. (2008). Ser um homem segundo a tradição? Fractal: Revista de Psicologia, 20, 437-445. Retrieved January 07, 2014, from http://www.scielo.br/scielo.php?script=sci_arttext\&pi$\mathrm{d}=$ S1984-02922008000200010\&lng=en\&tlng=pt. 10.1590/S198402922008000200010 .

Saffioti, H.I.B. (1987). O poder do macho. São Paulo: Moderna.

Saraiva, A.I.R.S. (2011). Da Grécia a Cronenberg ou por que existem as mulheres. Revista Estudos Feministas, 19, 329-349. Retrieved January 07, 2014, from http://www.scielo.br/scielo.php?script=sci_arttext\&pid=S0104-026X2011000200002\&lng=pt\&tlng=pt. $10.1590 /$ S0104-026X2011000200002.

Sedgwick, E.K. (2007). A epistemologia do armário. Cadernos Pagu, 28, 19-54. Retrieved January 07, 2014, from http://www.scielo.br/scielo.php?script=sci_arttext\&pi$\mathrm{d}=\mathrm{S} 0104-83332007000100003 \& \operatorname{lng}=$ pt\&tlng $=$ pt. 10.1590/ S0104-83332007000100003

Silva, C.V.D.G.F., \& Campos Filho, L.A.N. (2006). Gestão de Clubes de Futebol Brasileiros: Fontes Alternativas de Receita. Revista Sistemas \& Gestão, 1, 195-209, setembro a dezembro. Retrieved December 07, 2014, from http://www.uff.br/sg/index.php/sg/ article/viewArticle/13

Silva, S.G. (2000). Masculinidade na história: a construção 
cultural da diferença entre os sexos. Psicologia: Ciência e Profissão, 20, 8-15. Retrieved January 07, 2014, from http://www.scielo.br/scielo.php?script=sci_arttext\&pi$\mathrm{d}=\mathrm{S} 1414-98932000000300003 \& \operatorname{lng}=$ en\&tlng=es. 10.1590/ S1414-98932000000300003.

Silva, V.L.N. (2006). O preço de um sonho: a realidade do esporte que não é mostrada pela mídia. Revista Motrivivência, 27, 49-71.

Simon, R.L. (2006). El fútbol como fuente de valores morales. In C.R. Torres, and D.G. Campos (Eds), ¿La pelota no dobla? Ensayos filosóficos em torno al fútbol (pp.150-186). Buenos Aires: Libros del Zorzal.

Souza, W.M. (2010). Literatura homoerótica: o homoerotismo em seis narrativas brasileiras. Dissertação de Mestrado. Universidade Federal de Minas Gerais, Faculdade de Letras, Belo Horizonte, MG, Brasil. Retrieved September 02, 2014, from http://www. livrosgratis.com.br/arquivos_livros/cp153760.pdf

Stake, R.E. (1995). The Art of Case Study Research. Thousand Oaks, CA: Sage Publications.

Swain, T.N. (2009). Heterogênero: "Uma categoria útil de análise." Educar em Revista,35, 23-36. Retrieved January 25, 2014, from http://www.scielo.br/scielo.php?script=sci_arttext\&pi$\mathrm{d}=$ S0104-40602009000300003\&lng=pt\&tlng=pt. 10.1590/S010440602009000300003.

Thomas, J.R., Nelson, J.K. (2002). Métodos de pesquisa em atividade fisica $\left(3^{\text {rd }}\right.$ ed.). Porto Alegre: Artmed.

Townsend, M. (2013). Eight footballers say 'we're gay' but keep quiet in fear of fans. The Guardian. Retrieved August 31, 2014, from http://www.theguardian.com/world/2013/may/05/gay-footballersfear-reaction-of-fans

Vieira, R. (2001). Histórias de vida e identidades. Porto: Editora Afrontamento.

Vieira, S. (2009). Como elaborar questionários. São Paulo: Atlas.

Wagner, W. (1995). Social representations, group affiliation, and projection: knowing the limits of validity. European Journal of Social Psychology, 25, 125-140.

Weed, M. (2009). Research quality considerations for grounded theory research in sport \& exercise psychology. Psychology of Sport and Exercise, 10, 502-510.

Weinberg, R.S., \& Gould, D. (2001). Fundamentos da Psicologia do esporte e do exercício ( $2^{\text {nd }}$ ed.). Porto Alegre: Artmed.

Whitson, D. (1990). Sport in the Social Construction of Masculinity. In M.A. Messner, and D.F. Sabo (Eds), Sport, Men, and the Gender Order: Critical Feminist Perspectives (pp.19-29). Champaign: Human Kinetics Books.

\section{Authors' note}

Altair Moioli (http://lattes.cnpq.br/8590538130037930) is graduated in Physical Education, PhD in the Human Development and Technology graduate program at São Paulo State University, Rio Claro, Brazil. Professor at the Paulista University (UNIP). Coordinator of the Department of Sport Education of the city of São José do Rio Preto, Brazil, since 1993. Member of the Laboratory of Studies and Research in Sport Psychology at São Paulo State University (LEPESPE), Rio Claro, Brazil. His research includes issues related to soccer, physical education, sports psychology, human development and technologies. Altair is a scholarship recipient with CAPES (BEX 0227 / 13-7), and is part of a doctoral sandwich program at the University of Minho, Braga, Portugal. E-mail: amoiolli@uol.com.br

Afonso Antonio Machado (http://lattes.cnpq.br/9998824647536109) is graduated in physical education from Pontific Catholic University
Campinas, Brazil. He is a $\mathrm{PhD}$ in Education at the State University of Campinas, Brazil. Currently is a professor at the Institute of Biosciences, at the São Paulo State University, Rio Claro, Brazil. Advisor in the physical education, with emphasis on: emotional states, psychological identity of the sportsman, gender and masculinity in sport and sports psychological injuries. Dr. Machado is coordinator of the Laboratory of Studies and Research in Sport Psychology, graduate coordinator of the Human Development and Technology graduate program (DEHUTE) at São Paulo State University, Rio Claro, Brazil. E-mail: afonsoa@gmail.com

Marcelo Callegari Zanetti (http://lattes.cnpq.br/6927795193629892) graduated in physical education at the Faculty of Philosophy, Sciences and Letters of São José do Rio Pardo, Brazil. He is a PhD in Human Development and Technology at São Paulo State University, Rio Claro, Brazil, member of the Laboratory of Studies and Research in Sport Psychology (LEPESPE) at São Paulo State University, Rio Claro, Brazil. Currently he is a professor of physical education at the Paulista University (UNIP) and has experience in the following topics: emotional states, sports psychology, external interference in sport, emotional balance in sport and physical activity. E-mail: marceloczanetti@hotmail.com

Debra Frances Campbell (http://lattes.cnpq.br/6949180522458441) majored in both journalism and political science, and, also, received a master's degree in instructional systems technology from Indiana University, USA. Currently, she is a doctoral student in the Human Development and Technology graduate program at São Paulo State University, Rio Claro, Brazil. She researches themes in media violence, disability and media, the "culture of perfection," digital communications, scientific writing, and employs mixed and qualitative research methods. E-mail: campbell@rc.unesp.br

António Rui Gomes (http://www.degois.pt/visualizador/curriculum. jsp?key=4213636370806340) majored in sport psychology at the University of Minho, Braga, Portugal. Currently he is an assistant professor at the University of Minho, Braga, Portugal. Has numerous articles in professional journals, book chapters and books published in the field of sport psychology; works in social sciences with an emphasis in psychology. His professional activities in scientific production frequently include topics related to burnout, life skills, sports training, stress, positive experiences, and expertise, occupational stress, psychological development, parents and coach. E-mail: rgomes@psi.uminho.pt

\section{Corresponding author}

Altair Moioli

E-mail: amoiolli@uol.com.br

Manuscript received on June 11, 2013

Manuscript accepted on September 24, 2014

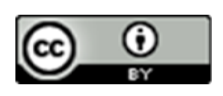

Motriz. The Journal of Physical Education. UNESP. Rio Claro, SP, Brazil - eISSN: 1980-6574 - under a license Creative Commons - Version 3.0 